\title{
Analysis on Development Countermove in Nantong
}

\author{
Wenzheng $\mathrm{Yu}^{1,2}$, Tianliang Chen ${ }^{1}$, Qi YingXiang ${ }^{2}$, Li Shao ${ }^{1}$ and Zhengrong Huang ${ }^{2}$ \\ ${ }^{1}$ College of Environmental Science and Engineering, Nanjing University of \\ Information Science \& Technology, Jiangsu Nanjing, 210044, China \\ ${ }^{2}$ College of public management, Nanjing University of Information Science \& \\ Technology, Jiangsu Nanjing, 210044, China
}

\begin{abstract}
This article choose Nantong, the city with rapid economic and social development in china as the research object. Using the statistical data of national economy in 1985-2011, for the standard of mean value of urbanization in Beijing and Shanghai, analyze the urbanization development level in recent years in Nantong by the analytic hierarchy process (AHP). The results showed that with a high level of economic and social life, the current urbanization rate of Nantong is $80 \%$, close to the standard level, population and geographical landscape urbanization level is about 2/3 of the standard level; among the individual indicators, the higher ones are the level of development of the second industry output value accounted for the proportion of GDP, road area per capita, per capita residential area, water penetration and urban gasification, which are above or close to the optimal level. However, compared with the optimal level, the gardens green area, annual electricity consumption, number of bus per ten thousand people, number of college students is lower. Therefore, for the future of Nantong urbanization, we should continue to adjust and improve the industrial structure, and gradually reduce the proportion of secondary industry, promote the urban landscape construction vigorously, speed up the improvement of public transport system and the development of further higher education.
\end{abstract}

Key words: Nantong, urbanization, development level, countermove

\section{Introduction}

Urbanization is the important symbol of human civilization in highly development. Urbanization is not only the objective trend of economic and social development, an important stage that human must go through, an important national symbol of industrialization and modernization, but also the important achievements of human civilization. As the largest developing country, the rate of urbanization in China is very fast. According to the research results from Chinese Academy of Social Sciences, the urban population exceeds the rural population for the first time in China's history in 2011; Urbanization was more than 50\%. Thus, Chinese people's way of living, production, occupational structure, consumer behavior and values will be taken place with profound changes.

Nantong is one of the first 14 coastal cities that are opening to the outside world in China. In June 2009, the State Council executive meeting formally made Jiangsu coastal development as a national strategy, and Nantong is one of the coastal cities. In recent years, the increasing population, rapid economic growth, urbanization of Nantong has been expanding fast, and the development speed is very quick. According to the sixth national census data bulletin of Jiangsu province in 2012, urbanization rate of Nantong reached 58.7\%, raise 26 percentage points more than in 2000. In the stage of rapid development of Nantong, to analyze and study the urbanization process, puts forward the related countermeasure of the city development, and provide a reference basis for improving the living environment, city planning and layout of the city and the ecological environment, building a conservation oriented city, has a certain practical significance to realize the sustainable development in 
Nantong city.

\section{Study Area}

Nantong has 3 districts, 2 counties, 2 economic and Technological Development Zone and 1 functional area, is one of the birthplace of modern industry in China, whose economy dominated by port, machinery, electronics, chemical, building etc. According to statistics, by the end of 2012 the city's resident population is 72.97 million people, GDP reached 455.87 billion RMB, three industrial structures was adjusted by 7.0: 54.5: 38.5 in 2011 to 7.0: 53.0: 40.0 in 2012, the continuous optimization of industrial structure is obvious. Strong momentum in the development of emerging industry, marine engineering equipment, new energy, new materials, biotechnology and new medicine, intelligent equipment and energy saving and environmental protection and other six major emerging industries grew rapidly, the regional economic were in a stage of rapid development, the development of urbanization faces great challenges.

\section{Data and Methods}

\subsection{Data}

The relevant data on urbanization in this article primarily choose the urban Statistical Yearbook of China (1985-2011) for total 27 years, while also referring to the Nantong Statistical Yearbook (1999-2011) and the Jiangsu Statistics Yearbook (1991-2011). Mainly select proportion of non-agricultural population, urban population density, second and third industries employment, GDP per capita, the average wage, the second and third industry output value accounted for the proportion of GDP, the proportion of built-up area, built-up area green coverage, gardens green area, road area per capita, per capita residential area, annual electricity consumption, city water penetration, city gasification rate, number of bus per ten thousand people, number of college students and so on, totally 17 key indicators.

\subsection{Methods}

This article mainly uses the method of analytic hierarchy process (AHP), supplemented by linear analysis method study on the process of urbanization. AHP is proposed by Sarti, a professor of American strategist Pittsburgh University in the early 1970 of the 20th century. Its methods of qualitative and quantitative analysis were on the basis of the element of decision-making cut into goals, standards, programs and other levels, it can better remove the adverse effects caused by subjective judgment. The most important role of AHP is filtering the indicators which can best reflect the level of urbanization. AHP main has five basic steps: establish a hierarchical model; constructing judgment matrix; Single sort; Consistency checking; Total sort levels. Since this method is relatively subjective, so must do the consistency test:

$$
\begin{gathered}
C I=\frac{\lambda_{\max }-n}{n-1} \\
C R=\frac{C I}{R I}
\end{gathered}
$$

CI - consistency of the judgment matrix index;

$\lambda_{\max }-$ maximum eigenvalue; 
$\mathrm{CR}$ - satisfactory consistency index;

RI - average consistency index.

\section{Establishment of Nantong Urbanization Development Index System}

Urbanization level is an important quantitative indicator which measures the degree of city's development, in the past, basically through urban built-up area and population to measure the level of urbanization. However, the degree of urban development is a comprehensive index which includes the region's economic, social, cultural and other aspects of development. Urban population and area is in the certain degree that can reflect the degree of a city's development and changes, in terms of statistics and data analysis is also very convenient, but can't reflect the urban comprehensive development situation, the significance of urban construction, planning, energy saving, environmental protection and sustainable development is not big. In addition, in our country, the urban population, built-up area and other official statistics are often subject to the influence of economic and urban development policies, such as urban zoning change and restructuring, household migration. Therefore, in order to reflect a more comprehensive level of urbanization, the feasibility and objectivity of the data acquisition were taken into account, urban population density, green space area, and totally 17 indicators were selected, and these indicators are divided into demographic, economic, geographical landscape and social life, four II class indicators (Figure 4-1); And according to the analytic hierarchy process (AHP) to deal with the index, the weight of each index value are obtained (Table 4-1).

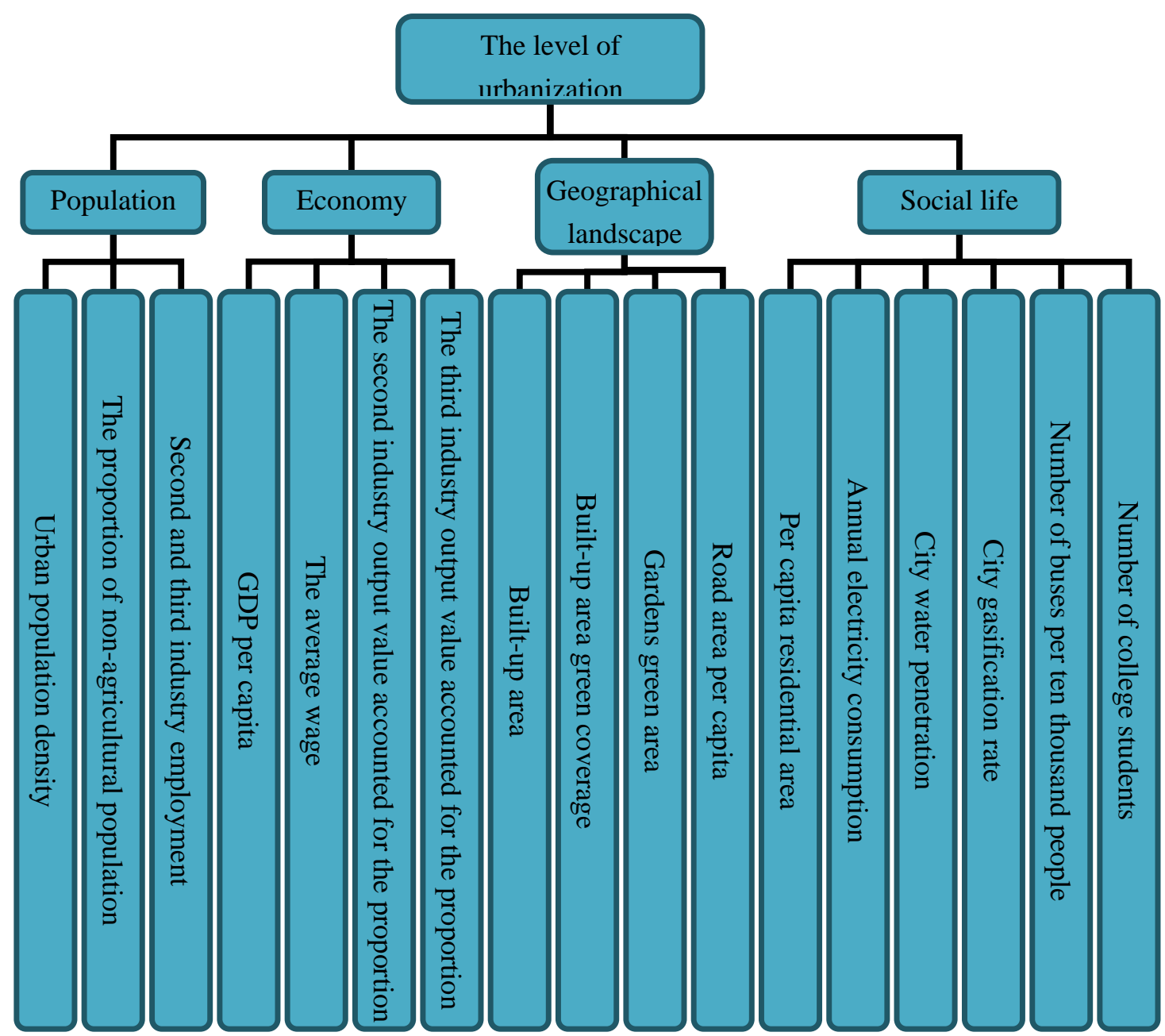

Figure 4-1. Evaluation System of Nantong Urbanization Quality 
Table 4-1. Evaluation System and Weight of Nantong Urbanization Quality

\begin{tabular}{|c|c|c|c|}
\hline & Category & Index & Weight \\
\hline \multirow{15}{*}{$\begin{array}{l}\text { The level of } \\
\text { urbanization } \\
\text { (A) }\end{array}$} & \multirow{3}{*}{$\begin{array}{l}\text { Population } \\
\qquad \begin{array}{l}\text { (B1) } \\
0.29\end{array}\end{array}$} & $\begin{array}{l}\text { Urban population density } \\
\left(\mathrm{km}^{2} \text { per capita }\right)(\mathrm{C} 1)\end{array}$ & 0.100978 \\
\hline & & $\begin{array}{l}\text { The proportion of non-agricultural population (\%) } \\
\text { (C2) }\end{array}$ & 0.100978 \\
\hline & & $\begin{array}{l}\text { Second and third industry employment } \\
\qquad(\%)(\mathrm{C} 3)\end{array}$ & 0.088073 \\
\hline & \multirow{4}{*}{$\begin{array}{l}\text { Economy } \\
\text { (B2) } \\
0.235\end{array}$} & $\begin{array}{l}\text { GDP per capita } \\
(\mathrm{RMB})(\mathrm{C} 4)\end{array}$ & 0.112832 \\
\hline & & $\begin{array}{l}\text { The average wage } \\
\text { ( RMB) (C5) }\end{array}$ & 0.053307 \\
\hline & & $\begin{array}{l}\text { The second industry output value accounted for the } \\
\text { proportion of GDP } \\
(\%)(\text { C6 })\end{array}$ & 0.0347 \\
\hline & & $\begin{array}{l}\text { The third industry output value accounted for the } \\
\text { proportion of GDP } \\
\qquad(\%)(\text { C7 })\end{array}$ & 0.05381 \\
\hline & \multirow{2}{*}{$\begin{array}{l}\text { Geographi } \\
\text { cal } \\
\text { landscap }\end{array}$} & $\begin{array}{l}\text { Built-up area } \\
(\%)(\mathrm{C} 8)\end{array}$ & 0.071534 \\
\hline & & $\begin{array}{l}\text { Built-up area green coverage } \\
\qquad(\%)(\mathrm{C} 9)\end{array}$ & 0.0613115 \\
\hline & \multirow{2}{*}{$\begin{array}{l}\mathrm{e} \\
(\mathrm{B} 3) \\
0.235\end{array}$} & $\begin{array}{l}\text { Gardens green area } \\
\text { (Hectare) }(\mathrm{C} 10)\end{array}$ & 0.051559 \\
\hline & & $\begin{array}{l}\text { Road area per capita } \\
\qquad\left(\mathrm{m}^{2}\right)(\mathrm{C} 11)\end{array}$ & 0.051089 \\
\hline & \multirow{4}{*}{$\begin{array}{l}\text { Social life } \\
\qquad \begin{array}{l}\text { (B4) } \\
0.24\end{array}\end{array}$} & $\begin{array}{l}\text { Residential area per capita } \\
\qquad\left(\mathrm{m}^{2}\right)(\mathrm{C} 12)\end{array}$ & 0.048024 \\
\hline & & $\begin{array}{l}\text { Annual electricity consumption } \\
\qquad \text { (Billion kwh) (C13) }\end{array}$ & 0.038904 \\
\hline & & $\begin{array}{l}\text { City water penetration } \\
\qquad(\%)(\mathrm{C} 14)\end{array}$ & 0.034296 \\
\hline & & $\begin{array}{l}\text { City gasification rate } \\
\qquad(\%)(\mathrm{C} 15)\end{array}$ & 0.04116 \\
\hline
\end{tabular}




\begin{tabular}{|l|c|c|c|}
\hline \multirow{2}{*}{} & \multirow{2}{*}{$\begin{array}{c}\text { Number of buses per ten thousand people } \\
(\mathrm{C} 16)\end{array}$} & 0.04116 \\
\cline { 2 - 3 } & Number of college students (C17) & 0.36456 \\
\hline
\end{tabular}

Put the average level of urbanization in Shanghai and Beijing as optimal standard, determine the level of urbanization in Nantong, established the urbanization index system of Nantong.

$$
\begin{aligned}
& F_{\mathrm{i}}=\frac{A_{\mathrm{i1}}}{A_{\mathrm{ia}}} \\
& F=\sum_{i=1}^{1 Y}\left(\frac{A_{i 1}}{A_{i 0}} \cdot Q_{i}\right) \\
& F_{E 1}=\sum_{i=1}^{3}\left(F_{\bar{i}} \times \frac{Q_{\bar{i}}}{\sum_{i=1}^{3} Q_{i}}\right) \\
& F_{E 2}=\sum_{i=4}^{T}\left(F_{\bar{i}} \cdot \frac{Q_{\bar{i}}}{\sum_{i=4}^{P} Q_{\bar{i}}}\right) \\
& F_{E a}=\sum_{i=\mathbb{Q}}^{11}\left(F_{\bar{i}} \cdot \frac{Q_{i \bar{i}}}{\sum_{i=\mathbb{1}}^{11} Q_{\bar{i}}}\right) \\
& F_{E 4}=\sum_{\overline{1}=12}^{1 \pi}\left(F_{\bar{i}} \cdot \frac{Q_{\bar{i}}}{\sum_{1=12}^{12} Q_{i}}\right)
\end{aligned}
$$

$\mathrm{A}_{0}-$ optimal standard;

$\mathrm{F}_{\mathrm{i}}$ - comparison value of $\mathrm{i}$ index;

$\mathrm{F}$ - urban comprehensive index;

$\mathrm{F}_{\mathrm{B} 1}$ - urbanization index of population;

$\mathrm{F}_{\mathrm{B} 2}-$ urbanization index of economy;

$\mathrm{F}_{\mathrm{B} 3}-$ urbanization index of geographical landscape;

$\mathrm{F}_{\mathrm{B} 4}$ - urbanization index of social life;

$A_{i 1}$ - actual value of $i$ index;

$\mathrm{A}_{\mathrm{i} 0}$ - optimal value of $\mathrm{i}$ index;

$\mathrm{Q}_{i}$ - weight of $\mathrm{i}$ index.

\section{Analysis on Urbanization of Nantong}

\subsection{Urbanization of Population}

It mainly reflected the agricultural population shifted to urban population which resulted in urban employment structures and related facilities changes. Calculated the urbanization rate of population $\left(\mathrm{F}_{\mathrm{B} 1}, 4-3\right)$ in 2010 was $69.6 \%$, which is the average of $69.9 \%$ in Beijing and Shanghai. Urbanization level of population in Nantong has been in a fluctuating upward trend, in 2005 appeared a sudden increase in 2005 that reached to $93 \%$, down to $69.6 \%$ in 2010 , which was mainly caused by the sharp rise of urban population density in 2005 and increased employment of the second and third industry, seen from Table 5-1, these two indicators respectively increased by $35 \%$ and $13.2 \%$ compared to 2000 ; In addition, due to the urban population density and non-agricultural population declined sharply, the index data in 2010 was down much more than in 2005, these two indicators respectively decreased by $89.3 \%$ and $11 \%$ compared to 2010 , which resulted the urbanization of population decrease by $23.4 \%$ 
compared to 2000. The proportion of non-agricultural population and employment of the second and third industry were tend to be steady growth, fluctuations in population density of Nantong is relatively large.

Table 5-1. Urbanization Level of Population in Nantong

\begin{tabular}{|c|c|c|c|c|c|c|c|}
\hline Num & Index & 1985 & 1990 & 1995 & 2000 & 2005 & 2010 \\
\hline C1 & Urban population density & $15.3 \%$ & $63 \%$ & $86.9 \%$ & $132 \%$ & $167 \%$ & $77.7 \%$ \\
\hline C2 & $\begin{array}{c}\text { The proportion of } \\
\text { non-agricultural population }\end{array}$ & $22.1 \%$ & $22.2 \%$ & $31.5 \%$ & $41 \%$ & $39 \%$ & $50 \%$ \\
\hline C3 & $\begin{array}{c}\text { Proportion of employment in } \\
\text { the second and third industry }\end{array}$ & $47.8 \%$ & $50.8 \%$ & $57.9 \%$ & $57 \%$ & 70. & $82.8 \%$ \\
B1 & Population & $27.5 \%$ & $45.1 \%$ & $58.8 \%$ & $77.6 \%$ & $93 \%$ & $69.6 \%$ \\
\hline
\end{tabular}

\subsection{Urbanization of Economy}

It mainly represented the urbanization level by total economy and economic structure to represent the urbanization level. Calculated the urbanization rate of economy $\left(\mathrm{F}_{\mathrm{B} 2}, 4-4\right)$ in Nantong 2010 was $90.6 \%$ that is reached to Beijing and Shanghai in economic terms alone. As the Table 5-2 shown, the fastest growth of GDP per capita was from 2000 to 2005, the growth rate reached 20.4\%; the second industry output value accounted for the proportion of GDP was far greater than in Beijing and Shanghai, which showed an increasing trend in recent years. And the industry is interested in bringing a huge challenge in city planning, living environment and ecological environment and other aspects, which has the largest contribution to the urbanization of economy. In addition, the average wage and the third industry output value in GDP is gradually reduced, so these two indicators are manifestation of modern urbanization key index, whose growth rate in Beijing and Shanghai is higher than in Nantong.

Table 5-2. Urbanization Level of Economy in Nantong

\begin{tabular}{|c|c|c|c|c|c|c|c|}
\hline Num & Index & 1985 & 1990 & 1995 & 2000 & 2005 & 2010 \\
\hline C4 & GDP per capita & $44.3 \%$ & $47.5 \%$ & $53.2 \%$ & $53.3 \%$ & $73.7 \%$ & $77.3 \%$ \\
\hline C5 & The average wage & $76 \%$ & $82.9 \%$ & $76.7 \%$ & $65.7 \%$ & $67.6 \%$ & $62.9 \%$ \\
\hline C6 & $\begin{array}{c}\text { The second industry output } \\
\text { value accounted for the } \\
\text { proportion of GDP }\end{array}$ & $68.4 \%$ & $122.5 \%$ & $123.4 \%$ & $134.9 \%$ & $158.3 \%$ & $164.1 \%$ \\
\hline C7 & $\begin{array}{c}\text { The third industry output } \\
\text { value accounted for the } \\
\text { proportion of GDP }\end{array}$ & $71.2 \%$ & $60.4 \%$ & $70 \%$ & $73.9 \%$ & $61.7 \%$ & $65.4 \%$ \\
\hline B2 & Economy & $64.9 \%$ & $77.5 \%$ & $77.2 \%$ & $77.4 \%$ & $88.2 \%$ & $90.6 \%$ \\
\hline
\end{tabular}

\subsection{Urbanization of Geographical Landscape}

Geographical landscape is mainly reflecting a situation of urban infrastructure. 
Calculated the urbanization rate of geographical landscape $\left(\mathrm{F}_{\mathrm{B} 3}, 4-5\right)$ in Nantong 2010 was $67.7 \%$ which is the average of Beijing and Shanghai. The gardens green area in Nantong was much lower than in Beijing and Shanghai that only reached $67.7 \%$ of the average. This result mainly led to the rapid growth of built-up area during this period. The built-up area in Nantong is larger than in Beijing and Shanghai during 1995 to 2005, and once reached 249\% of the average in Beijing and Shanghai (Table 5-3). In addition, the road area per capita has been higher than the average level of both Beijing and Shanghai, except in 2005 was $80.2 \%$ of them. The above analysis showed that the development of urbanization in Nantong was unbalanced, the public facilities yet to be perfected.

Table 5-3. Urbanization Level of Geographical Landscape in Nantong

\begin{tabular}{|c|c|c|c|c|c|c|c|}
\hline Num & Index & 1985 & 1990 & 1995 & 2000 & 2005 & 2010 \\
\hline C8 & Built-up area & $28.6 \%$ & $106.1 \%$ & $176.1 \%$ & $249 \%$ & $152.9 \%$ & $61.7 \%$ \\
\hline C9 & $\begin{array}{c}\text { Built-up area green } \\
\text { coverage }\end{array}$ & $6 \%$ & $87.3 \%$ & $89.7 \%$ & $103 \%$ & $110.7 \%$ & $81.9 \%$ \\
\hline C10 & Gardens green area & $7.4 \%$ & $5.7 \%$ & $5.5 \%$ & $5.9 \%$ & $6.1 \%$ & $9.5 \%$ \\
\hline C11 & Road area per capita & $116.7 \%$ & $134.5 \%$ & $189.7 \%$ & $100.9 \%$ & $80.2 \%$ & $116.7 \%$ \\
\hline B4 & Geographical landscape & $37.2 \%$ & $85.5 \%$ & $119.5 \%$ & $125.9 \%$ & $94.2 \%$ & $67.7 \%$ \\
\hline
\end{tabular}

\subsection{Urbanization of social life}

Social life is mainly related to people's daily life like housing, water and electricity, number of buses and education. Calculated the urbanization rate of social life $\left(\mathrm{F}_{\mathrm{B} 4}, 4-6\right)$ in Nantong 2010 was $94.3 \%$ which was in a steady growth started from 1985. The residential area per capita in Nantong was far more than in Beijing and Shanghai; water penetration and urban penetration rate has reached the level of these two cities; However, annual electricity consumption and the number of college students were much less than in both Beijing and Shanghai; The gap on number of buses per ten thousand people in Nantong was so large compared with in Beijing and Shanghai that in the future urban strategic planning should be pay attention to the improvement of public transport (Table 5-4).

Table 5-4. Urbanization Level of Social Life in Nantong

\begin{tabular}{|c|c|c|c|c|c|c|c|}
\hline Num & Index & 1985 & 1990 & 1995 & 2000 & 2005 & 2010 \\
\hline C12 & Residential area per capita & $82.6 \%$ & $80.1 \%$ & $79.3 \%$ & $127.5 \%$ & $169.9 \%$ & $177 \%$ \\
\hline C13 & $\begin{array}{l}\text { Annual electricity } \\
\text { consumption }\end{array}$ & $5 \%$ & $8.8 \%$ & $9.9 \%$ & $5.7 \%$ & $7.3 \%$ & $10.5 \%$ \\
\hline C14 & City water penetration & $98.4 \%$ & $108.3 \%$ & $100 \%$ & $100 \%$ & $100 \%$ & $100 \%$ \\
\hline C15 & City gasification rate & $11.6 \%$ & $51.4 \%$ & $84.4 \%$ & $99.3 \%$ & $99.9 \%$ & $98.2 \%$ \\
\hline C16 & $\begin{array}{c}\text { Number of buses per ten } \\
\text { thousand people }\end{array}$ & $36.1 \%$ & $32.7 \%$ & $27.2 \%$ & $34.6 \%$ & $56.7 \%$ & $21.5 \%$ \\
\hline C17 & Number of college students & $3.7 \%$ & $4.3 \%$ & $5.2 \%$ & $8.2 \%$ & $11.6 \%$ & $14.7 \%$ \\
\hline B4 & Social life & $45.1 \%$ & $53.9 \%$ & $58.8 \%$ & $79.9 \%$ & $93.9 \%$ & $94.3 \%$ \\
\hline
\end{tabular}




\section{Conclusions}

According to the data from 1985 to 2010 in Nantong, put every five years as a period, the overall level of Nantong urbanization development and its individual indicators were analyzed with the standard level of urbanization development in Beijing and Shanghai. The urbanization rate of Nantong was $80 \%$ in 2010, as the standard level of urbanization, $69.6 \%$ to population, $90.6 \%$ to economy, $67.7 \%$ to geographical landscape and $94.3 \%$ to social life, which considering that urbanization of population and geographical landscape need to be strengthened in the future.

Since the 1990s, level of urbanization in Nantong has made great achievements, compared with the standard level, economic and social life were in a high level of urbanization, while the population and geographical landscape of urbanization is about $2 / 3$ of standard level. From the overall perspective, level of urbanization in Nantong has been improved, which made great progress in all aspects of urban development. Among the 17 indicators, the higher ones are level of the second industry output value accounted for the proportion of GDP, road area per capita, residential area per capita, water penetration and urban gasification, which are above or close to standard level. The second industry output value accounted for the proportion of GDP increased year after year, on which the economic development of Nantong is relying more and more, that is not conducive to its urbanization; Compared to standard level, only $9.5 \%$ to gardens green area, $21.5 \%$ to number of buses per ten thousand people and $14.7 \%$ to number of college students. To accelerate the process of urbanization in Nantong, should continue to adjust and improve the industrial structure, gradually reduce the proportion of the second industry, vigorously promote the urban landscape construction, speed up the improvement of public transport system and further development of higher education.

\section{Acknowledgments}

This work is supported by the Dynamic mechanism of desertification in response to climate change in Qinghai Lake (41375160), evaluation of solar energy resources and the related studies of efficiency and effectiveness of photovoltaic (1213013) and effect of urbanization on climate change_ a case study of Yangtze River delta (2010JDXM027). Prof. Wenzheng Yu is the corresponding author.

\section{References}

[1] http://www.nantong.gov.cn/art/2013/3/28/art_5961_1116870.html The website for Nantong government.

[2] L. Aijun, T. Zhihao, L. Chunfeng and Z. Yifei, "Discussion of the method for urbanization level Measure with synthetic index", Economic Geography, vol. 1, (2004), pp. 43-46.

[3] T. Yuejin, "Method of Quantitative Analysis", Beijing: China Renmin University Press, (2002), pp. 110-160.

[4] Z. Feng and L. Yuanyuan, "The Urbanization Level Measurement of Xi'an Based on Analytic Hierarchy Process", Xi' an Jiaotong University (Social Sciences), vol. 26, no. 2, pp. 41-45.

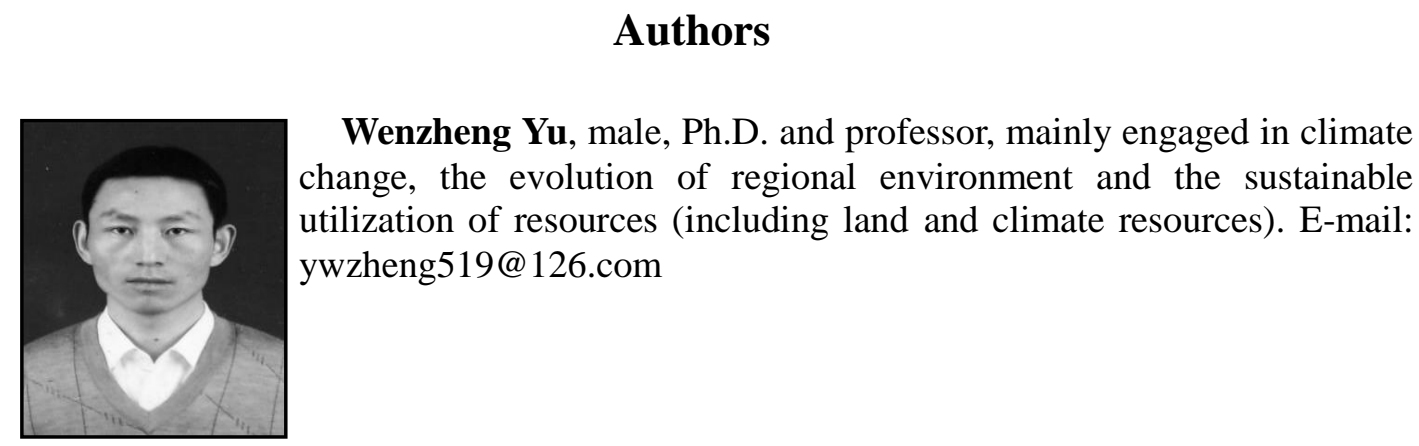




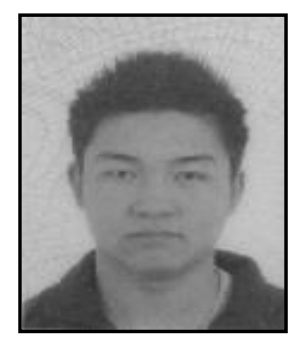

Tianliang Chen, male, master candidate, mainly engaged in effect of urbanization on climate change. E-mail: g1z217@163.com

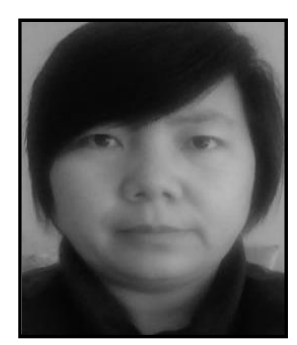

Qi Yingxiang, female, master of China University of Political science and Law, associate professor, mainly engaged in the research about policy of resources and environment.

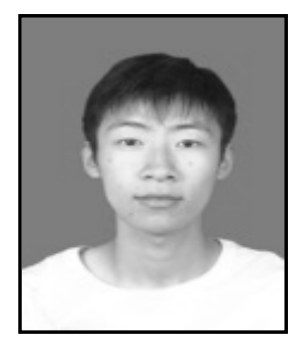

Li Shao, male, master candidate, mainly engaged in effect of urbanization on climate change. E-mail: shaoli20081317@163.com. 
International Journal of $u-$ and e- Service, Science and Technology

Vol.7, No.2 (2014) 